\title{
Mortality and cancer incidence in chloralkali workers exposed to inorganic mercury
}

\author{
L Barregård, G Sällsten, B Järvholm
}

\begin{abstract}
Mortality and cancer incidence were studied in men exposed to inorganic mercury at eight Swedish chloralkali plants where individual biological monitoring data were available. Urinary mercury excretion has declined from about $200 \mu \mathrm{g} / 1$ during the 1950 s to less than $50 \mu \mathrm{g} / 1$ today. These workers had also been exposed to chlorine and static magnetic fields. At some of the plants there had been a low degree of exposure to asbestos. In total, 1190 men had been monitored for at least one year between 1946 and 1984. Their mortality and cancer incidence were compared with those of the general male population. Mortality from all causes was not significantly increased (rate ratio $=1 \cdot 1)$. Cardiovascular mortality was slightly increased (rate ratio $=1 \cdot 3 ; 95 \%$ CI 1.01.5) for no known reason. An excess of lung tumours was seen (rate ratio $=2 \cdot 0 ; 95 \%$ CI 1.03.8), possibly caused by previous exposure to asbestos. Mortality from non-malignant diseases of the brain and the kidneys, the main target organs in mercury poisoning, was not increased, nor was the incidence of brain tumours ( 3 observed $v 1 \cdot 1$ expected) or kidney tumours ( 3 observed $v 1.9$ expected).
\end{abstract}

Elemental mercury vapour $\left(\mathrm{Hg}^{\circ}\right)$ is readily absorbed through the lungs. It is oxidised in the blood and various organs to the divalent form $\left(\mathrm{Hg}^{2+}\right)$. In the elemental form, however, it can pass the blood-brain and placental barriers. ${ }^{1}$ The critical organs after exposure to mercury vapour are the central nervous system and the kidneys. Symptoms of poisoning include neuraesthenic symptoms, personality changes, and tremor. ${ }^{1}$ Exposure to inorganic mercury may also cause glomerular or tubular renal disease. Cases of glomerulonephritis and an increased prevalence of glomerular proteinuria and tubular enzymuria have been shown in groups occupationally exposed to mercury. ${ }^{2-4}$

Department of Occupational Medicine, Sahlgren's University Hospital, S-412 66 Gothenburg, Sweden L Barregård, G Sällsten, B Järvholm
Inorganic mercury is eliminated by urinary and faecal excretion. The main part of the body burden is eliminated with a half time of about two months ${ }^{5}$ but compartments with long half times probably exist. ${ }^{1}$ In individuals with occupational exposure urinary or blood mercury are used for biological monitoring.

Mercury compounds are genotoxic, mainly by inhibiting the mitotic spindle, but the direct mutagenic effect of the inorganic forms seems to be low. ${ }^{67}$ Cytogenetic studies in subjects exposed to mercury vapour have in most cases shown no effects on human chromosomes. ${ }^{89}$ Few studies of cancer in animals after exposure to mercury compounds have been reported and none used inhalation of mercury vapour as the route of exposure. ${ }^{11}$

Three epidemiological studies have been published on the mortality or cancer morbidity in groups with occupational exposure to inorganic mercury. In a British study the proportional mortality in nonmalignant genitourinary tract diseases was reported to be higher in chloralkali workers than in other factory workers. ${ }^{12}$ In a United States cohort of workers at a plant in the nuclear weapons programme mortality was studied in a subgroup exposed to mercury vapour. There was a slight excess of deaths from lung cancer in all subgroups. The authors, however, considered the excess related to other factors than the exposure to mercury. ${ }^{13}$ In a recent Swedish study the incidence of brain tumours among dentists and dental nurses was about double that expected. Exposure to mercury from dental amalgam was discussed as a possible causative factor. ${ }^{14}$

The aim of the present study was to examine the mortality and cancer morbidity in Swedish chloralkali workers with long term, and previously high, exposure to inorganic mercury.

\section{Material and methods}

The mercury cell process has been used for the production of chlorine at eight Swedish chloralkali plants. The subjects were selected from the files of the company health and personnel units of these plants. All Swedish men were selected who had been monitored with urinary or blood mercury $(\mathrm{U}-\mathrm{Hg}$, $\mathrm{B}-\mathrm{Hg}$ ) for more than one year until 1984: 1190 employees met these criteria. 
Table 1 Biological monitoring at the eight Swedish chloralkali plants

\begin{tabular}{|c|c|c|c|}
\hline \multirow[b]{2}{*}{ Plant No } & \multirow[b]{2}{*}{ Hg cells used } & \multicolumn{2}{|c|}{ Biological monitoring } \\
\hline & & $U-H g$ & $B-H g$ \\
\hline $\begin{array}{l}1 \\
2 \\
3 \\
4 \\
5 \\
6 \\
7 \\
8\end{array}$ & $\begin{array}{l}1926- \\
1968- \\
1918- \\
1957-82 \\
1945-77 \\
1964- \\
1946-83 \\
1936-\end{array}$ & $\begin{array}{l}1960-70 \\
1969-78 \\
1946-73 \\
1959-77 \\
1959-71 \\
1964- \\
1961-84 \\
1957-\end{array}$ & $\begin{array}{l}1971- \\
1969- \\
1973- \\
1975-84 \\
1971-83 \\
1976- \\
1980- \\
1980-\end{array}$ \\
\hline
\end{tabular}

\section{SUBJECTS}

Subjects were identified by the national ten digit identification numbers assigned to all Swedish citizens. Vital status and causes of death were ascertained from the National Population Register and the National Bureau of Statistics. None of the men was lost to follow up. Underlying causes of death were coded according to the eighth revision of the International Classification of Disease (ICD). The cancer incidence of the cohort was obtained from the Swedish Cancer Register. Mortality was ascertained from 1958 to 1984 and cancer incidence from 1958 to 1982 because the registers include complete data from these periods. The observed mortality and cancer incidence were compared with those of the general male population using calendar year, sex, and age stratified (five year age groups) rates. The rate ratios were calculated with $95 \%$ confidence limits using a Poisson distribution. ${ }^{15}$ The latency time was calculated from the year of the first urinary or blood mercury analysis. For subjects employed before biological monitoring started, this implies that the latency times are shorter than if they had been calculated from the first year of exposure. The latter was, however, not known for these subjects.

\section{EXPOSURE}

Biological monitoring of exposure to mercury started at one of the plants as early as 1946 and became general about 1960 (table 1). In the 1960s and earlier urinary mercury was analysed using the dithizone method. Later, cold vapour atomic absorption spectrophotometry and blood mercury analyses were introduced.

The exposure to mercury was reduced substantially in the Swedish chloralkali industry during the late 1960 s and 1970 s. The mean urinary mercury excretion declined from about $200 \mu \mathrm{g} / 1$ during the $1950 \mathrm{~s}$ to $150 \mu \mathrm{g} / 1$ in the $1960 \mathrm{~s}$ and less than $50 \mu \mathrm{g} / 1$ today.

For each individual a yearly mean $\mathrm{U}-\mathrm{Hg}$ or $\mathrm{B}-\mathrm{Hg}$ was calculated from his monitored values during each calendar year. An accumulated mercury dose was calculated by adding these yearly mean $\mathrm{Hg}$ values. In subjects where only blood mercury had been deter- mined $\mathrm{B}-\mathrm{Hg}$ was transformed into $\mathrm{U}-\mathrm{Hg}$ by multiplying by $2 \cdot 5$, a crude ratio of $\mathrm{U}-\mathrm{Hg} / \mathrm{B}-\mathrm{Hg}$ suggested in published reports. ${ }^{16}$ As mentioned above, the total accumulated $\mathrm{Hg}$ dose is not known for those individuals exposed before biological monitoring started in the chloralkali industry. We therefore also divided the material into subgroups with "complete" and "incomplete" biological monitoring.

When dose specific ratios of mortality and cancer incidence were calculated, person-years were accumulated when the subjects had reached the lower limit of the accumulated $\mathrm{Hg}$ dose in the exposure groups.

A survey was also made of the use of asbestos at the chloralkali plants at different periods. From these data it was noted which subjects might have been exposed to asbestos.

\section{Results}

About $25 \%$ of the subjects had an accumulated mercury dose exceeding 1000 years $\mu \mathrm{g} / 1$ (table 2). Of 1190 subjects, 457 had a possible, in most cases low grade, exposure to asbestos.

\section{CANCER INCIDENCE AND MORTALITY}

Table 3 shows the observed and expected incidence of cancer. The incidence of lung cancer was twice the expected, just statistically significant. No excess of tumours in the brain and kidneys, critical organs for mercury, could be shown. Observed and expected numbers, however, were small. In table 4 the data on lung cancer are compared with the accumulated mercury dose. There was no dose response relation and the data in each stratum are sparse. Most cases of lung cancer occurred among the men with possible exposure to asbestos. In the subgroup with complete biological monitoring, and for whom the "true" latency time was well known, the rate ratio (all tumours) increases with increasing latency time (table 5).

No excess deaths from non-malignant diseases of the central nervous system or the kidneys could be shown but the numbers are too small to permit a risk assessment (table 6).

There was an increased mortality from diseases of the circulatory system, when allowing for at least ten years of latency time. This tendency was seen for ischaemic heart diseases and cerebrovascular dis-

Table 2 Accumulated mercury dose in the study population

\begin{tabular}{llll}
\hline & $\begin{array}{l}\text { All subjects } \\
(n=1190)\end{array}$ & $\begin{array}{l}\text { With complete } \\
\text { data }(n=816) \\
\%\end{array}$ & $\begin{array}{l}\text { With incomplete } \\
\text { data }(n=374) \\
\%\end{array}$ \\
\hline$<1000$ & 74 & 83 & $\begin{array}{l}\% \\
1000-2000\end{array}$ \\
$>2000$ & 16 & 13 & 25 \\
\hline
\end{tabular}

$\star$ Years $\mu \mathrm{g} / \mathbf{l}(\mathrm{U}-\mathrm{Hg})$. 
Table 3 Observed and expected cancer incidence between 1958 and 1982 in 1190 men exposed to inorganic mercury at eight Swedish chloralkali plants

\begin{tabular}{|c|c|c|c|c|c|c|c|}
\hline \multirow[b]{2}{*}{$I C D 8$} & \multirow[b]{2}{*}{ Site } & \multicolumn{2}{|c|}{ No latency } & \multicolumn{4}{|c|}{$\geqslant 10$ Years of latency time } \\
\hline & & Obs & $\operatorname{Exp}$ & Obs & $\operatorname{Exp}$ & Obs/exp & $(95 \% C I) \ddagger$ \\
\hline $\begin{array}{l}140-209 \\
150-159 \\
162 \cdot 1 \\
163 \cdot 0 \\
185 \\
188 \\
189 \\
191 \\
200-209\end{array}$ & $\begin{array}{l}\text { All† } \\
\text { Digestive organs } \\
\text { Lung } \\
\text { Pleura } \\
\text { Prostate } \\
\text { Urinary bladder } \\
\text { Kidney } \\
\text { Brain } \\
\text { Lymphatic, haematopoietic system }\end{array}$ & $\begin{array}{r}64 \\
13 \\
13 \\
1 \\
12 \\
5 \\
4 \\
4 \\
4\end{array}$ & $\begin{array}{c}65 \\
18 \\
7 \cdot 4 \\
0 \cdot 1 \\
11 \\
4 \cdot 3 \\
3 \cdot 0 \\
2 \cdot 2 \\
5 \cdot 2\end{array}$ & $\begin{array}{r}51 \\
10 \\
10 \\
1 \\
10 \\
5 \\
3 \\
3 \\
3\end{array}$ & $\begin{array}{r}42 \\
12 \\
4 \cdot 9 \\
0 \cdot 1 \\
8 \cdot 6 \\
2 \cdot 9 \\
1 \cdot 9 \\
1 \cdot 1 \\
3 \cdot 2\end{array}$ & $\begin{array}{l}1 \cdot 2 \\
0 \cdot 8 \\
2 \cdot 0^{\star} \\
1 \cdot 2 \\
1 \cdot 7 \\
1 \cdot 6 \\
2 \cdot 7 \\
0 \cdot 9\end{array}$ & $\begin{array}{l}(0 \cdot 9-1 \cdot 6) \\
(0 \cdot 4-1 \cdot 5) \\
(1 \cdot 0-3 \cdot 8) \\
(0.6-2 \cdot 1) \\
(0 \cdot 6-4 \cdot 1) \\
(0 \cdot 3-4 \cdot 7) \\
(0 \cdot 5-7 \cdot 7) \\
(0 \cdot 2-2 \cdot 7)\end{array}$ \\
\hline
\end{tabular}

${ }^{\star} \mathrm{p}<0.05$.

+ Apart from the sites mentioned, the following tumours were found: malignant melanoma 2, salivary gland 2 , muscle 1 , eye 1 , unspecified 2. $\$ 95 \%$ Confidence limits of the rate ratio.

eases. It was found to be most evident below age 60 (table 7). There was no dose response relation when cardiovascular mortality was related to the accumulated mercury dose.

\section{Discussion}

SELECTION, DIAGNOSIS, AND EXPOSURE ASSESSMENT

A criterion for inclusion in the cohort was biological monitoring. At least since the late 1950 s all permanently employed cell room workers have been monitored. To our knowledge the files of the company health and personnel units were complete. There was no indication that the files of dead or unhealthy workers had been removed.

The diagnoses of the Swedish Cancer Register are of good quality. Also the classification of the underlying causes of death by the National Bureau of Statistics is considered valid for most cases. ${ }^{17}$

The accumulated mercury dose is based on a few monitored $\mathrm{Hg}$ values a year and is thus a somewhat crude measure. Misclassification also results from the fact that many subjects were exposed before biological monitoring started (table 2). For some of those individuals, the calculated mercury dose may be grossly underestimated and the latency times misleading. Misclassification would, however, be non-differential and tend to weaken a possible dose response relation.

Table 4 Incidence of lung cancer (ICD 8, No 162.1) by accumulated mercury dose and possible exposure to asbestos $(\geqslant 10$ years of latency time)

\begin{tabular}{lccl}
\hline Hg Dose & Obs & Exp & Obs/exp \\
\hline All & 10 & 4.9 & $2 \cdot 0$ \\
$<1000$ & 3 & 1.9 & $1 \cdot 6$ \\
$1000-2000$ & 5 & 1.5 & 3.3 \\
$>2000$ & 2 & 1.5 & 1.3 \\
Possible exposure & 9 & $4 \cdot 1$ & $2 \cdot 2$ \\
to asbestos $\dagger$ & & & \\
\hline
\end{tabular}

$\star$ Years $\cdot \mu \mathrm{g} / \mathrm{l}(\mathrm{U}-\mathrm{Hg})$.

†Possible employment when asbestos was used.

\section{COMPARISON GROUP}

In this study national rates were used for calculating the expected mortality and incidence of cancer. This is not an ideal procedure. The so called healthy worker effect in occupational cohorts is well known. ${ }^{1819} \mathrm{~A}$ typical rate ratio in gainfully employed workers is $0.8-0.9$ when compared with the general population. Our comparisons would therefore result in an underestimation of a possible toxic effect from occupational factors.

The regional incidence rates of lung cancer and cardiovascular death rates of the counties where the chloralkali plants are located were studied and compared with national rates. The plants are spread all over Sweden, none in a big city. Using regional rates would affect our results only marginally. (The number of expected lung cancers would be about 4 instead of 4.9 (table 3 ); expected cardiovascular deaths would be about 75 instead of 70 (table 6).)

\section{LUNG CANCER AND CARDIOVASCULAR DISEASES: POSSIBLE CONFOUNDERS}

The incidence of lung cancer and the cardiovascular mortality were higher than expected in this cohort of chloralkali workers. When discussing the possible effect of their exposure to mercury, it is necessary to assess some potentially confounding factors.

Exposure to asbestos is a well known risk factor for lung cancer. At one of the chloralkali plants (No 7) diaphragms of asbestos had been used and changed

Table 5 Incidence of cancer (ICD 8, No 140-209) by latency time. Only subjects with complete data from biological monitoring $(n=816)$

\begin{tabular}{lccll}
\hline Latency time & Obs & Exp & Obs/exp & $(95 \% C I)$ \\
\hline Any & 27 & 21 & 1.3 & $(0.8-1.9)$ \\
$<10 \mathrm{y}$ & 7 & 11 & 0.6 & $(0.3-1 \cdot 3)$ \\
$10-19 \mathrm{y}$ & 11 & 6.9 & 1.6 & $(0.8-2.9)$ \\
$\geqslant 20 \mathrm{y}$ & $9 \dagger$ & 3.1 & $2.9 \star$ & $(1.3-5 \cdot 5)$
\end{tabular}

${ }^{\star} \mathrm{p}<0.05$.

†Digestive 3, lung 2, urinary bladder 2, prostate 1, unspecified 1. 
Table 6 Observed and expected mortality during 1958-84 in 1190 men exposed to inorganic mercury at eight Swedish chloralkali plants

\begin{tabular}{|c|c|c|c|c|c|c|c|}
\hline \multirow[b]{2}{*}{$I C D 8$} & \multirow[b]{2}{*}{ Cause of death } & \multicolumn{2}{|c|}{ No latency } & \multicolumn{4}{|c|}{$>10$ years of latency time } \\
\hline & & Obs & $\operatorname{Exp}$ & Obs & $\operatorname{Exp}$ & Obs/exp & $(95 \% \mathrm{CI}) \dagger$ \\
\hline $\begin{array}{c}390-458: \\
410-412 \\
430-438 \\
140-209 \\
460-519 \\
290-357 \\
580-584\end{array}$ & $\begin{array}{l}\text { All } \\
\text { Circulatory diseases: } \\
\quad \text { Ischaemic heart disease } \\
\text { Cerebrovascular disease } \\
\text { Malignant tumours } \\
\text { Respiratory diseases } \\
\text { Mental disorders and nervous system } \\
\text { Nephritis and nephrosis }\end{array}$ & $\begin{array}{r}180 \\
104 \\
79 \\
15 \\
41 \\
6 \\
3 \\
1\end{array}$ & $\begin{array}{l}195 \\
94 \\
70 \\
14 \\
40 \\
7 \cdot 6 \\
3 \cdot 1 \\
0 \cdot 8\end{array}$ & $\begin{array}{r}147 \\
88 \\
66 \\
14 \\
35 \\
5 \\
3 \\
0\end{array}$ & $\begin{array}{r}136 \\
70 \\
52 \\
11 \\
29 \\
6 \cdot 0 \\
2 \cdot 0 \\
0.4\end{array}$ & $\begin{array}{l}1 \cdot 1 \\
1 \cdot 3^{\star} \\
1 \cdot 3^{\star} \\
1 \cdot 3 \\
1 \cdot 2 \\
0 \cdot 8 \\
1 \cdot 5 \\
-\end{array}$ & $\begin{array}{l}(0 \cdot 9-1 \cdot 3) \\
(1 \cdot 0-1 \cdot 5) \\
(1 \cdot 0-1 \cdot 6) \\
(0 \cdot 7-2 \cdot 2) \\
(0 \cdot 8-1 \cdot 7) \\
(0 \cdot 3-1 \cdot 9) \\
(0 \cdot 3-4 \cdot 4) \\
-\end{array}$ \\
\hline
\end{tabular}

$\star \mathrm{p}<0.05$.

$+95 \%$ Confidence limits of the rate ratio.

daily during 1932-49. The exposure level was estimated to be 1-5 fibres/ml for half the workforce. At four plants, where asbestos had been used as sealing cord for the cells until 1970, the estimated levels were only about $0 \cdot 1 \mathrm{f} / \mathrm{ml}$. At the other three plants there had been no exposure to asbestos.

With this degree of exposure one would hardly expect the incidence of lung cancer to be twice normal. ${ }^{20}$ On the other hand, at the plant where asbestos diaphragms were used, three cases of lung cancer were seen among the workers with a possible exposure to asbestos compared with less than one case expected. Moreover, there was one case of mesothelioma. Therefore we consider exposure to asbestos to be a possible cause of the increased incidence of lung cancer in this cohort.

Smoking is an obvious potential confounder when studying lung cancer and cardiovascular mortality. When talking to old foremen and workers, we got the impression that those employed in the chloralkali industry did not smoke more heavily than other Swedish men. Smoking was generally prohibited in the cell rooms where the hydrogen gas was liable to explode. Furthermore, after a "sniff" of chlorine, smoking was often impossible for many hours. We interviewed a random sample of the 81 members of the cohort born 1900-39 and alive in 1984 (table 8). Assuming that the proportion of smokers and exsmokers exceeds that of the general population by $5 \%$ each, an estimation of the amount of confounding was made. ${ }^{21}$ The assumed smoking habits could only

Table 7 Cardiovascular mortality (ICD 8: 390-458) by age at death $(\geqslant 10$ years of latency time)

\begin{tabular}{lllll}
\hline Age at death & Obs & Exp & Obs/exp & $(95 \% C I) \dagger$ \\
\hline All & 88 & 70 & $1 \cdot 3 \star$ & $(1 \cdot 0-1 \cdot 5)$ \\
559 & 17 & $8 \cdot 7$ & $2 \cdot 0^{\star}$ & $(1 \cdot 1-3 \cdot 1)$ \\
$60-69$ & 24 & 23 & $1 \cdot 0$ & $(0 \cdot 7-1 \cdot 6)$ \\
$70-74$ & 22 & 18 & $1 \cdot 3$ & $(0 \cdot 8-1 \cdot 9)$ \\
$75-84$ & 25 & 21 & $1 \cdot 2$ & $(0 \cdot 8-1 \cdot 8)$ \\
\hline
\end{tabular}

${ }^{\star} \mathrm{p}<0.05$.

$+95 \%$ Confidence limits of the rate ratio. account for a rate ratio of about $1 \cdot 1$ for lung cancer and much less for cardiovascular mortality. So, smoking habits can probably not explain our findings.

In recent years shiftwork has been mentioned as a possible risk factor for cardiovascular diseases. ${ }^{22}$ The mechanism is unknown. In the present cohort about half the subjects were shiftworkers. If shiftwork does increase the risk of cardiovascular disease this might at least partly explain our results.

These workers had also been exposed to chlorine and strong static magnetic fields. The temperature in the cell rooms was sometimes high. None of these factors has, however, been proved to cause lung cancer or cardiovascular deaths.

Of the three classic individual risk factors associated with cardiovascular disease, smoking was mentioned above. We know nothing about cholesterol levels or blood pressure in the cohort members. We can see no reason, however, why subjects with high cholesterol levels or high blood pressure should work more often at chloralkali plants.

\section{CHEMICAL EXPOSURE AND CARDIOVASCULAR DISEASE}

Little information is available about environmental agents (other than lifestyle factors) associated with cardiovascular disease. ${ }^{23} 24$

Carbon disulphide and nitrates are the best documented cardiotoxic occupational risk factors. Among the metals, there is some evidence that lead may cause hypertension and there are also reports of

Table 8 Smoking habits 1985 in a random sample of cohort members born 1900-39 and alive in 1984

\begin{tabular}{lll}
\hline Smoking habits & Sample $(n=81) \ddagger$ & Swedish menil \\
\hline Smokers & $33 \%$ & $30 \%$ \\
Ex-smokers $\dagger$ & $52 \% \%$ & \\
Never smoked & $15 \%$ & \\
\hline
\end{tabular}

^Daily smoking of cigarettes or pipe.

†More than six months.

Eighty two men approached, 81 responded.

$\$ 95 \%$ Confidence limits $23-43 \%$.

\|Adjusted for age of the sample (data taken from the National Bureau of Statistics, Sweden). 
a cardiotoxic effect after heavy exposure to arsenic. Cobalt exposure could result in cardiomyopathy but the number of reported cases with industrial exposure is small. Selenium deficiency was associated with cardiomyopathy in the Keshan region of China, and some authors have claimed a negative correlation between selenium levels and cardiovascular deaths. ${ }^{25}$

Methyl mercury and inorganic mercury salts have been shown to cause hypertension in animals. ${ }^{26}$ In these studies, however, the route of exposure was oral or intra-arterial and the doses used were high.

In a cross sectional study of miners heavily exposed to inorganic mercury an increased prevalence of hypertension was seen (D O Marsh, personal communication). In an extensive cross sectional study by Smith et al of United States and Canadian chloralkali workers the tendency was rather the opposite. ${ }^{16}$ In the United States mortality study of workers exposed to mercury vapour ${ }^{13}$ there was no increased mortality from cardiovascular diseases (D L Cragle, personal communication) but no allowance was made for latency. If exposure to mercury does indeed increase cardiovascular mortality hypertension could be a possible mechanism. Another reason could be the effect of mercury on selenium metabolism. ${ }^{1}$

From experimental and previous epidemiological studies on exposure to mercury there is, therefore, limited evidence of cardiovascular toxicity. In the present study there was no dose response relation between accumulated mercury exposure and cardiovascular deaths. Also, the confounding effect of life style factors or shift work cannot be totally ruled out. Further studies of hypertensive and other cardiovascular diseases after exposure to mercury seem appropriate.

\section{KIDNEY AND BRAIN}

A slight effect on renal tubules is common among Swedish chloralkali workers even at the present exposure levels. ${ }^{27}$ This, however, would probably not lead to any evident kidney disease.

Glomerulonephritis could be more serious. In the British proportional mortality study of 91 chloralkali workers there were two deaths from nephritis or nephrosis between 1945 and 1960 . There were three deaths (one in connection with systemic lupus erythematosus) among 375 non-exposed dead workers in a reference group. Data on age distributions and exposure to mercury are lacking. In a study at the same plant the proportional mortality from kidney disease 1972-9 was not increased among workers exposed to mercury. ${ }^{12}$

In the United States mortality study ${ }^{13}$ there was only one case of nephritis compared with two expected during the observation period 1953-78. In our study there was also only one case versus $0 \cdot 8$ expected (without latency). That subject had been exposed to mercury for at least four years. No other specific cause of the disease was found.

In total, these studies indicate that the mortality from non-malignant kidney disease in chloralkali workers exposed to mercury has not been substantially increased during the past few decades. It should, however, be noticed that a mortality study today is not a sensitive method for detecting nephritis in an exposed population when dialysis and transplantations are in general use.

There were three kidney tumours versus 1.9 expected (table 3 ). The numbers were about the same (without latency) in the United States mortality study. ${ }^{13}$ The cohorts are too small to detect a moderately increased risk. The power of the present study allows a chance of $80 \%$ to show a fourfold increase of kidney tumours ( $\alpha=0.05$, one-tailed).

Non-malignant central nervous system mortality could be discussed in a fashion similar to that on nephritis. Mercury certainly affects the brain but probably not in a way that increases mortality in nonmalignant diseases.

Our finding of three brain tumours versus $1 \cdot 1$ expected (table 3 ) seems to support the report among dental personnel ${ }^{14}$ but it is also consistent with no increased risk. The present study has a low power ( $\beta=0.8$ to show a sixfold increase of brain tumours). The mean exposure to mercury vapour in chloralkali workers is and has been five to ten times higher than that of dental personnel. ${ }^{28}$ The point estimate of the rate ratio (and $95 \% \mathrm{CI}$ ) was $1.8(1 \cdot 2-2 \cdot 7)$ among dental personnel (all brain tumours) and $2 \cdot 7(0 \cdot 5-7 \cdot 7)$ in the chloralkali workers. One could claim, therefore, that if exposure to mercury vapour was the cause of brain tumours in dental personnel there is hardly any linear dose response relation.

\section{Conclusion}

In summary the incidence of lung cancer was increased in the chloralkali workers, possibly due to the previous use of asbestos. Cardiovascular mortality was slightly raised, the reason for this being unknown. The mortality from non-malignant diseases of the brain and the kidneys, the main target organs after exposure to mercury, was not significantly increased, nor was the incidence of brain or kidney tumours.

The medical staff at the chloralkali plants, Dr Bertil Dahlberg, Dr Berit Holmgren, Dr Bo Nyström, Dr Urban Blomqvist, Dr Bengt Tufvesson, Dr Andrejs Viskers, and others gave valuable help in forming the cohort, as did the engineers, the trade unions, and former employees. Professor Staffan Skerfving and Gunnar Thiringer commented on the planning and the manuscript. The Swedish Work Environment Fund provided economic support. 
1 Berlin M. Mercury. In: Friberg L, et al, eds. Handbook on the toxicology of metals. Vol 2. Amsterdam: Elsevier, 1986: $387-445$.

2 Tubbs RR, Gephardt GN, McMahon JT, et al. Membranous glomerulonephritis associated with industrial mercury exposure. Am J Clin Pathol 1982;77:409-13.

3 Kazantzis G, Schiller KFR, Asscher AW, Drew RG. Albuminuria and the nephrotic syndrome following exposure to mercury and its compounds. $Q J \mathrm{Med}$ 1962;31:403-18.

4 Roels H, Lauwerys R, Buchet JP, et al. Comparison of renal function and psychomotor performance in workers exposed to elemental mercury. Int Arch Occup Environ Health 1982;50:77-93.

5 Hursh JB, Clarkson TW, Cherian MG, Vostal JV, Maille RV. Clearance of mercury $\left({ }^{107} \mathrm{Hg},{ }^{203} \mathrm{Hg}\right)$ vapor inhaled by human subjects. Arch Environ Health 1976;31:302-9.

6 Ramel C. Genetic effects. In: Friberg L, Vostal J, eds. Mercury in the environment. Cleveland: CRC Press, 1972:169-82.

7 Andersen O, Rönne M, Nordberg GF. Effects of inorganic metal salts on chromosome length in human lymphocytes. Hereditas 1983;98:65-70.

8 Verschaeve L, Tassignon JP, Lefevre M, de Stoop P, Susanne C. Cytogenetic investigations on leukocytes of workers exposed to metallic mercury. Environ Mutagen 1979;1:259-68.

9 Mabille V, Roels H, Jacquet P, Leonard A, Lauwerys R. Cytogenetic examination of leukocytes of workers exposed to mercury vapour. Int Arch Occup Environ Health 1984; 53:257-60.

10 Druckrey H, Hamperl H, Schmäl D. Cancerogene Wirkung von metallischen Quicksilber nach intraperitonealer Gabe bei Ratten. Z Krebsforsch 1957;61:511-9.

11 Kazantzis G. Role of cobalt, iron, lead, manganese, mercury, platinum, selenium and titanium in carcinogenesis. Environ Health Perspect 1981;40:143-61.

12 Duffield DP, Paddle GM, Woolhead G. A mortality study of non-malignant genitourinary tract disease in electrolytic mercury cell room employees. J Soc Occup Med 1983;33: $137-40$.

13 Cragle DL, Hollis DR, Qualters JR, Tankersley WG, Fry SA. A mortality study of men exposed to elemental mercury. J Occup Med 1984;26:817-21.

14 Ahlbom A, Norell S, Nylander M, Rodvall Y. Dentists, dental nurses, and brain tumours. Br Med J 1986;292:662.

15 Bailar JC III. Significance factors for the ratio of a Poisson variable to its expectation. Biometrics 1964;20:639-43.

16 Smith RG, Vorwald AJ, Patil LS, Mooney TF. Effects of exposure to mercury in the manufacture of chlorine. $\mathrm{Am}$ Ind Hyg Assoc J 1970;31:687-700.

17 de Faire U, Friberg L, Lorich U, Lundman T. A validation of cause-of-death certification in 1156 deaths. Acta Med Scand 1976;200:223-8.

$18 \mathrm{McMichael}$ AJ. Standardised mortality ratios and the "healthy worker effect": scratching beneath the surface. $J$ Occup Med 1976;18:165-8.

19 Monson RR. Observations on the healthy worker effect. J Occup Med 1986;28:425-33.

20 Hughes J, Weill $\mathrm{H}$. Asbestos exposure-quantitative assessment of risk. Am Rev Respir Dis 1986;133:5-13.

21 Järvholm B, Thiringer G. Epidemiological studies of lung cancer, influence of smoking habits. Europ $J$ Respir Dis 1980;61 (suppl 107):125-9.

22 Åkerstedt T, Knutsson A, Alfredsson L, Theorell T. Shift work and cardiovascular disease. Scand $J$ Work Environ Health 1984;10:409-14.

23 Rosenman KD. Cardiovascular disease and environmental exposure. Br J Ind Med 1979;36:85-97.

24 Kurppa K, Hietanen E, Klockars M, et al. Chemical exposures at work and cardiovascular morbidity. Scand $J$ Work Environ Health 1984;10:381-8.

25 Salonen JT, Alfthan G, Huttunen JK, Pikkarainen J, Puska P Association between cardiovascular death and myocardial infarction and serum selenium in a matched-pair longitudinal study. Lancet 1982;ii:175-9.

26 Carmignani M, Boscoli P. Cardiovascular homeostasis in rats chronically exposed to mercuric chloride. Arch Toxicol 1984;suppl 7:383-8.

27 Barregård L, Hultberg B, Schütz A, Sällsten G. Enzymuria in workers exposed to inorganic mercury. Int Arch Occup Environ Health 1988;61:65-9.

28 Frykholm KO. Exposure of dental personnel to mercury during work. Swed Dent J 1970;63:763-72.

Accepted 3 April 1989 